\title{
Childhood, Education and Digital Media Mediation Strategies
}

\author{
Pierpaolo Limone ${ }^{1} \&$ Maria Grazia Simone ${ }^{2, *}$ \\ ${ }^{1}$ Department of Humanities. Letters, Cultural Heritage, Education Sciences, University of \\ Foggia, PO Box 71121, Foggia, Italy \\ ${ }^{2}$ Faculty of Psychology, eCampus On Line University, Via Isimbardi, 10, 22060 Novedrate \\ $\mathrm{CO}$, Italy
}

*Corresponding author: Faculty of Psychology, eCampus On Line University, PO Box 80143, Napoli, Italy. E-mail: mariagrazia.simone@uniecampus.it

Received: May 5, 2020 Accepted: May 29, 2020 Published: June 25, 2020

doi:10.5296/ije.v12i2.17302 URL: https://doi.org/10.5296/ije.v12i2.17302

\begin{abstract}
The paper aims to contribute to developing some educational mediation strategies, useful for those who educate in the family and at school, to support children in their first experiences with digital media and the net.

Digital technologies are already present in the child's living environments and, just like them, are characterized by a very rapid development. The task of those who do research and those who educate is to know the styles of use, the experiences, the learning, the exploratory maneuvers of the world that very young children perform thanks to digital technology. It should also be considered that, at times, they may be a few clicks away from content and images unsuitable for their age.
\end{abstract}

The paper, through the Systematic Review approach, reviews the most recent scientific literature on the subject and analyzes the results of some important international research projects on the subject.

The intent of the work, obviously, is not to provide exhaustive answers, always valid criteria and easy generalizations.

With regard to the relationship between childhood and digital media, the paper outlines shared tracks of educational work in the life contexts of the little ones (especially in the family and at school) and reasons to promote further, future investigations in this area.

Keywords: digital media, children, media education, educational mediation, teacher training 


\section{Introduction}

The research questions, which the paper intends to satisfy, are essentially two: can children be accompanied, in the family and in nursery school, in a fruition of digital devices that is advantageous for their particular evolutionary moment? If so, how?

The consumption of digital technology by children in the early childhood phase continues to grow and that they access the net at an ever lower age.

Nonetheless, socio-educational policies seem to ignore this specific age group, directing their attention almost exclusively to older children, not wanting to recognize early childhood an active role in digital media use. There is now a vast scientific literature on the presence and use of educational technologies at school. The same cannot be said about the domestic consumption of digital technology by very young children who has had, so far, little attention as an effective research topic. Consequently, the methodological indications on what they can explore and learn through digital media are scarce and, sometimes, contradictory.

The study of the relationship between the very young and digital technologies, in a pedagogical perspective, is a very recent research topic, not yet sufficiently explored in the scientific field (Chaudron, 2015; Haddon \& Holloway et al., 2018).

The prevailing interest appears to be focused on deepening styles and methods of fruition typical of subsequent age groups (Ólafsson \& Livingstone et al., 2014): there is a small number of studies conducted on nursery school, even less on domestic consumption practices (Holloway et alii., 2013; Plowman et alii 2012), while the main attention seems to fall on the dimension of online risk.

Already almost twenty years ago S. Livingstone (2003) denounced a research gap on the relationship between early childhood and digital media, attributing it to the will of scientists to cultivate sectorial investigative interests, rather than giving life to a shared and interdisciplinary commitment.

Yet the very young have become a considerable and loyal segment of consumers of digital technologies: they have the opportunity to connect to the internet through a variety of devices (tablets, smartphones, computers, touchscreen devices, etc.) and at the most varied times of their day.

The task of those who do research and those who educate at school and in the family cannot ignore the implementation of effective mediation practices in the relationship between the child and technology, also considering that, at times, they can be a few clicks away from content and images unsuitable for their age.

Effective educational mediation strategies are needed in the relationship between children and digital media.

Educational mediation means activating a dynamic process, generating a transactional space, a condition in which children, through digital media and under the supervision of adults, test themselves, play, discover, experiment, compare with peers. In this way, educational 
mediation causes growth and development both at the level of the identity of the child and within their family and school context.

It is now known that, in every age of development, digital technology responds to specific needs and performs specific functions (entertainment, information, learning, socialization ... and much more) also in childhood and pre-adolescence (Tisseron, 2016); less is known about the relationship between the little ones, these new devices and the repercussions on the cognitive, emotional, relational sphere, etc. The fact is that, for many of them, the digital screen is a regular playfellow and also represents a magical object.

The increase in the number of preschoolers who use digital technology requires a more effective understanding of the ways in which the latter mediates their encounter with reality, a systematic educational attention in the living spaces and on the actual practices carried out by children, as well as a reflection on the skills they need to interact in the vast world of digital media.

It would be too easy and reductive to attribute the weight of having eroded the possibility, for childhood, of playing in the traditional way without taking into consideration the many social, cultural, economic, anthropological changes that have progressively changed the playing time of the new one's generations.

The consideration of the dimensions of risk and safety during use certainly represents a very important and essential theme, which already feeds many research projects and investigative interests of scholars. However, these aspects should be accompanied by the reflection on the nature of digital knowledge, skills and competences that the young child develops in the pre-school segment as significant recreational and learning opportunities, far beyond the simple dimension of entertainment alone.

Increasingly, to ensure the socio-emotional well-being of the very young, expressions such as "protect" and "empower" are used (Holloway, Green, Livingstone, 2013). However, there is no need to remain perched on the prevention front and do it defensively. To these dimensions it would also be important to add the recognition of the validity, in the preschool age group, of certain experiences and as many learnings gained thanks to digital media, able to advantageously prepare the little ones to conveniently target the subsequent stages of development.

\section{Research Method}

Even in the presence of immaturity in language, in writing and reading skills, in eye-manual coordination, thanks to the touch screen and swipe technology, children, even under three years of age, can now make significant experiences, unthinkable in the past their age, and well before they can walk or speak.

Digital media and the network, for "technological childhood" (Limone, 2010; 2019), represent a great experiential and playful reserve in which to perform the most varied activities: playing online, enjoying videos on YouTube and similar platforms (Burroughs, 


\section{Macrothink}

2017; Buzzi, 2012) while, after reaching school age, the game is accompanied by the search for information, the execution of school tasks, the socialization among peers (Childwise, 2012).

We wanted to deepen the state of the art through the approach known as "Systematic Review".

This is an investigative strategy initially born in the medical field and used to implement, in the international scientific literature of a sector, a comprehensive review of the research most relevant to our object of investigation, the results of which may present good levels of generalizability.

The identification of the studies carried out and the identification of the data sources took place through the browsing of pedagogical research databases and through the hand searching of articles in scientific journals that can be consulted online.

In this way it was possible to select three large and recent international research projects:

- Toddlers and Tablets;

- EU Kids Online;

- Young Children (0-8) and Digital Technology.

The identification of these project initiatives took place through a careful selection that relied on the following indicators:

- international character of the partnership;

- presence of scholars from the academic world;

- interdisciplinarity of the research teams;

- numerical size of the sample;

- impact factor of scientific publications;

- online visibility of the products and the official research website.

For reasons of space, we will not talk here about the individual projects and their results, to which we refer by consulting the substantial documentation available online for each of them.

Here we will briefly present those which, from our perspective, are the most interesting results that emerged from these project initiatives, reading them in the light of the most recent international scientific literature on early childhood and digital media.

\section{Analysis of Results}

\subsection{Characteristics of Childhood Use}

Younger children grow up in domestic and school environments "digitally fluent" (Palaiologou, 2016) but this does not automatically make them dependent on technology and 
the network. The enjoyment appears modeled by the family habits, values and attitudes of the parents who are constantly observed by the children in their media practices. Of this, the adults often appear unaware. The consumption of technology by the child is mainly individual, with a clear preference for the tablet. It seems significant that digital activities, in most cases, do not replace pre-existing interests but complement them. Many of the studies taken into consideration have focused on the combination of opportunities / risks associated with the use of digital media and the network and, sometimes, neglecting other aspects worthy of attention. It emerged that children have little awareness of the dangers associated with online. Sometimes, despite the supervision of adults and the presence of protective filters, they have accidentally come across contents that are not suitable for their age. Younger children appear more vulnerable and may even "feel distressed" (Holloway et al., 2013). When they lose in an online game session, when they are socially excluded from games by friends or when some family member improperly uses their social profiles

\subsection{The Parents' Point of View}

Parents have a tendentially positive opinion about digital technologies but complain of some problems in their management within the daily routine of the family.

Mothers and fathers are aware of some benefits brought by digital devices that their children use. They identify some forms of advantage but underestimate them, perhaps prejudicially, by giving greater consent to traditional cultural practices, typical of face-to-face interaction (Plowman \& Stevenson et al., 2012).

Many parents of younger children often use touchscreen technology to "keep them busy" while they are also busy with something else (Stephen et al., 2013). Mothers and fathers don't do the same with older children (Haddon \& Holloway, 2018). These parents do not worry about any inappropriate content and contacts that the children may run into. They claim to be physically with them while they surf. At the same time, they appeared rather uninformed about the actual digital activities usually carried out by their children.

Mothers and fathers believe that the problem of online risk can be addressed ... when children are older and are very worried about potential abuse and associated health problems (Livingstone et alii, 2015). For this reason, they exercise parental mediation of a restrictive nature and say they are well disposed to receive advice and indications from the school.

\section{Conclusions}

To satisfy the research questions formulated at the beginning of the paper, below are some intervention criteria that, in the different living spaces, can help educators to support children, from the early stages of their development, in a advantageous relationship with the net and digital technologies.

\subsection{Rules}

Clear and non-negotiable rules of use must be provided to children, to apply in every living space (home, school, grandparents' house, etc.). 
To encourage children's acceptance of the rule, its co-creation and sharing with other people (uncles, neighbors, friends, etc.) who have children of the same age can be useful. The respect of the rules allows to a regular structuring of the day and not to neglect other activities in free time, also preventing the possible "binge" daily of digital technology.

The problem, in fact, does not lie in the use tout court by the very young but, obviously, in the abuse. As has been proven, in fact, an excess of stimulation received by new digital media in the first years of life could be penalizing because it will even be accompanied by a replacement of relational skills (Small \& Vorgan, 2008).

Only the projecting of precise methodological lines of media education, shared among school educators, family members and operators in their free time, can generate advantageous opportunities for fruition and learning through digital media. So is possible to guarantee the ability to build interpersonal relationships, the promotion of creativity, the development of social skills also thanks to digital technology.

\subsection{Family-school Cooperation}

The task of media education asks to be supported and shared by the family and the school in a relationship of virtuous collaboration between them, and between the various living environments in which the child grows. It can generate mutual recognition and direct involvement in a framework of educational co-responsibility.

The school-family relationship is complex, in continuous transformation and sometimes full of critical issues ... but essential.

Consumer education in digital technology in early childhood can be an opportunity to establish new forms of dialogue between the two most important educational agencies.

Starting from the comparison, and from the understanding that derives from it, it is possible, for the school and for the family, to discover themselves as interconnected educational spaces capable of collaborating for a shared educational project.

It is necessary to structure, around the children, a common educational ground that accompanies them, without alarmism and prejudices, along the paths of media use in terms of dialogue and broad collaboration between those who have the task of educating (Simone, 2008). Co-responsibility creates opportunities for reflection and planning to address, from a systemic perspective, important issues and common problems of the education of the new generations to digital.

\subsection{Parental Mediation}

Children in early childhood do not yet have their own point of view on technology.

Parental mediation is therefore the main device for promoting a fruitful meeting with digital technologies.

It is always recommended that educators, at school or in the family, are constantly present when the child surfs and do not allow themselves to see, in the digital device, a second cheap 
babysitter, after television, as has emerged from some research.

The child also learns to stay in the world by imitating adult behavior. The result is an inevitable adult action to model the children behavior towards digital media and the net, sometimes unconsciously. Parental media habits have been shown to significantly influence their children's exposure to the media and their opinion on what is the appropriate daily time limit for them (Rek \& Kovacic, 2019).

Effective mediation strategies require consistent adults in their actions, valid and positive behavioral models in the field of media use as in all other life situations. It is about ensuring a constant and participatory presence, a lively and concrete interest in the activities that children carry out online. In the case of cartoons, for example, perhaps not all parents know that it is definitely not recommended to expose those who are under 3, 4 years to passive watching, especially if on the screen there are unceasing images, with sometimes incomprehensible plots. The child needs to understand and emotionally control the messages received. Inability to understand and manage such a complex stimulus and absence of symbolic reworking through dialogue with the adult are negative factors (Bonaiuti \& Calvani et al., 2017) and predisposing uncomfortable situations. Applying the reward / punishment mechanism, invoking the restriction and taking sides in favor of total prohibition are not profitable strategies for regulating the use of digital technology; on the contrary, they fuel curiosity and desirability.

\subsection{Teacher Training}

Young children "get serious" with technology, in the sense that they develop important learning opportunities and have significant online experiences, as well as spending fun time with digital devices. Nursery school, more than primary school, must take more recognition of it by recognizing the validity of digital activities carried out by children. Teachers need to be trained

Technology, in nursery school, must be introduced through careful planning, in the light of didactic objectives well defined on an experiential, playful, informative and cognitive level to make the teachers of the interlocutors competent and active also on this theme.

The offer of suitable training opportunities for the family and other educational services can make the school the right driving force to create awareness of the potential, opportunities and any inappropriate use of digital technology by children, with a particular attention to situations of social unease (Livingstone et al., 2011), where the critical issues can be greater.

\section{References}

Bonaiuti, G., Calvani, A., Menichetti, L., \& Vivanet, G. (2017). Le tecnologie educative. Roma: Carocci.

Burroughs, B. (2017). YouTube Kids: The App Economy and Mobile Parenting. Social Media+Society, 3(1). https://doi.org/10.1177/2056305117707189 
Buzzi, M. (2011). What Are Your Children Watching on YouTube? In Cipolla-Ficarra F., Veltman K., Verber D., Kammüller F. (Eds.), Advances in New Technologies, Interactive Interfaces and Communicability. Berlin: Springer.

Chaudron, S. (2015). Young Children (0-8) and digital technology: A qualitative exploratory study across seven countries. Publications Office of the European Union.

Childwise. (2012). The Monitor Pre-school Report 2012: Key behaviour patterns among 0 to 4 year olds. Norwich, England: Childwise.

Haddon, L., Holloway, D., \& Green, L. et al. (2018). The parent-child-app learning assemblage: Scaffolding early childhood learning through app use in the family home. In N. Kucirkova et alii (Eds.), The Routledge International Handbook of Playing and Learning with Technology in Early Childhood. Abingdon, UK: Routledge.

Holloway, D., Livingstone, S., \& Green, L. (2013). Zero to eight. Young children and their internet use. London: EU Kids Online.

Limone, P. (2010). Lo studio della cultura mediale infantile e il dibattito sulla mutata concezione dell'infanzia. In S. Colazzo (a cura di). Il Sapere Pedagogico, Roma: Armando.

Limone, P. (2019). La realtà ludica dell'infanzia tecnologica. In M. G. Simone (a cura di), Lo sguardo. Percorsi per l'educazione dell'infanzia. Bari: Progedit

Livingstone, S. (2003). Children's use of the internet: Reflections on the emerging research $\begin{array}{lllll}\text { agenda. New } \quad \text { Media } \quad \& \quad \text { Society, } & \text { 5(2), }\end{array}$ https://doi.org/10.1177/1461444803005002001

Livingstone, S., Haddon, L., Görzig, A., \& Ólafsson, K. (2011). Risks and safety on the internet: the perspective of European children: full findings and policy implications from the EU Kids Online survey of 9-16 year olds and their parents in 25 countries. London, UK: EU Kids Online.

Livingstone, S., Mascheroni, G., Dreier, M., Chaudron, S., \& Lagae, K. (2015). How parents of young children manage digital devices at home: The role of income, education and parental style. EU Kids Online, London, UK: London School of Economics and Political Science.

Ólafsson, K., \& Livingstone, S. (2016). Children under five and digital technologies: implications for early years pedagogy. European Early Childhood Education Research Journal, 24(1), 1-20. https://doi.org/10.1080/1350293X.2014.929876

Plowman, L., Stevenson, O., Stephen, C., \& McPake, J. (2012). Preschool children's learning with technology at home. Computers \& Education, 59(1), 30-37. https://doi.org/10.1016/j.compedu.2011.11.014

Rek, M., \& Kovacic, A. (2019). Media and Preschool Children: The Role of Parents as Role Models and Educators. Medijske Studije, 18, 27-42. https://doi.org/10.20901/ms.9.18.2 


\section{Macrothink}

Simone, M. G. (2008). Infanzia e gioco digitale. Problemi e prospettive. Studi e Ricerche, n. 15.

Small, G., \& Vorgan, G. (2008). iBrain: surviving the Technological Alteration of the Modern Mind. New York: Harper-Collins.

Stephen, C., Stevenson, O., \& Adey, C. (2013). Young children engaging with technologies at home: the influence of family context. Journal of Early Childhood Research, 11(2), 149-164. https://doi.org/10.1177/1476718X12466215

Tisseron, S. (2016). 3-6-9-12. Diventare grandi all'epoca degli schermi digitali. Brescia: La Scuola.

\section{Note}

Note 1. The project deepens the knowledge of the opportunities, risks and online safety of European children from school age up to 16 years. Therefore, he is not directly interested in younger children. Nonetheless, it is apparently appropriate to consider its significance and the richness of the analysis perspectives, also regarding the 0-6 year segment.

\section{Copyright Disclaimer}

Copyright for this article is retained by the author(s), with first publication rights granted to the journal.

This is an open-access article distributed under the terms and conditions of the Creative Commons Attribution license (http://creativecommons.org/licenses/by/3.0/). 